\title{
DIÓgENES REBOUÇAS E O EPUCS: PLANEJAMENTO URBANO E ARQUITETURA NA BAHIA, 1947-1950
}

Nivaldo Vieira de Andrade Junior

\section{Resumo}

O Escritório do Plano de Urbanismo da Cidade do Salvador (EPUCS) teve um papel fundamental não só no planejamento urbano da capital baiana, como a historiografia já registrou, mas também na consolidação da arquitetura moderna e no processo de autonomização do campo arquitetônico no Estado. Além dos pioneiros levantamentos, estudos e propostas realizados em sua primeira fase (1943-1947), sob a coordenação de Mário Leal Ferreira, o EPUCS, na sua segunda fase (1947-1950), sob a coordenação de Diógenes Rebouças, terminou por se constituir, informalmente, no primeiro escritório de projetos urbanísticos e arquitetônicos da Bahia.

\section{Palavras-chave:}

Diógenes Rebouças - planejamento urbano - Salvador

\section{Abstract}

The Urban Planning Office for the City of Salvador (Escritório do Plano de Urbanismo da Cidade do Salvador - EPUCS) had an essencial role not only in the urban planning of the Capital of Bahia, as historiography has already registered, but also on the consolidation of modern architecture and on the process of autonomization of the architectural field in the State of Bahia. Besides the pioneers surveys, studies and proposals carried out in its first phase (1943-1947), while coordinated by Mário Leal Ferreira, EPUCS, in its second phase (1947-1950), under the coordination of Diógenes Rebouças, it has constituted itself, informally, in the first office in Salvador focused on urban and architectural design.

\section{Keywords:}

Diógenes Rebouças - urban planning - Salvador

\section{Introdução}


O Escritório do Plano de Urbanismo da Cidade do Salvador (EPUCS), criado na virada de 1942 para 1943, teve um papel fundamental não só no planejamento urbano da capital baiana, como a historiografia já registrou, mas também na consolidação da arquitetura moderna e no processo de autonomização do campo arquitetônico no Estado. Além dos pioneiros levantamentos e estudos realizados sobre Salvador, que dotaram seus técnicos de um aprofundado conhecimento dos problemas e potencialidades da capital baiana, o EPUCS terminou por se constituir, informalmente, em um verdadeiro escritório de projetos urbanísticos e arquitetônicos - o primeiro com essas características no Estado.
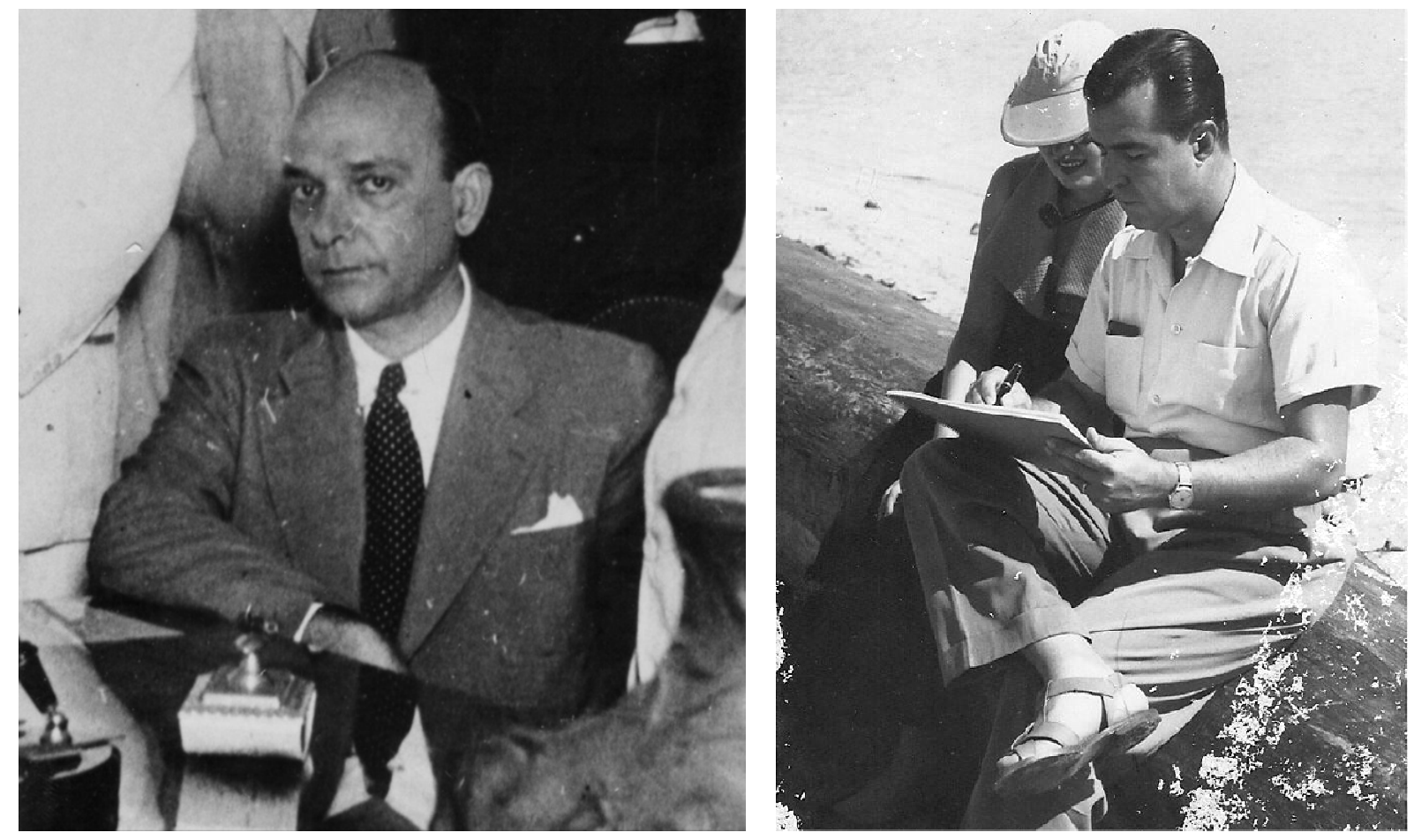

Figuras 01 e 02: Mário Leal Ferreira, no dia da assinatura do $1^{\circ}$ contrato com a Prefeitura (à esquerda) e Diógenes Rebouças (à direita).

Fontes: Arquivo Diógenes Rebouças - CEAB/FAUFBA; Arquivo pessoal Ronan Rebouças Caires de Brito).

A historiografia costuma associar o EPUCS ao seu fundador e primeiro coordenador, o engenheiro baiano Mário Leal Ferreira (FIGURA 01) ${ }^{1}$. Entretanto, outro engenheiro baiano desempenhou um papel de importância equivalente em um

\footnotetext{
${ }^{1}$ Mario Leal Ferreira, nascido em Santo Amaro, era engenheiro geógrafo pela Escola Politécnica da Bahia e engenheiro civil pela Escola Nacional de Engenharia do Rio de Janeiro. Especializou-se em engenharia sanitária em Harvard, nos Estados Unidos, e foi bolsista da Rockfeller Foundation entre 1930 e 1932. Foi Professor Livre Docente da cadeira de "Higiene, saneamento e urbanismo" da Escola Nacional de Engenharia e lecionou a disciplina "higiene da habitação" na Escola Nacional de Belas Artes. Exerceu diversos cargos públicos nos Estados do Rio de Janeiro, Rio Grande do Sul e São Paulo, sempre em áreas afins à engenharia sanitária. (FERNANDES, GOMES \& SAMPAIO, 1999, p. 507)
} 
segundo momento: Diógenes Rebouças (FIGURA 02) ${ }^{2}$, que coordenou o setor paisagístico do EPUCS da criação do escritório até a morte precoce de Ferreira, em 1947, quando assume a coordenação geral, cargo que mantém até 1950.

\section{Mário Leal Ferreira e o Plano do EPUCS}

Desde 1939, a Prefeitura de Salvador vinha realizando contatos com escritórios do Rio de Janeiro, como a firma Coimbra Bueno, visando à contratação de um plano de urbanismo para a capital baiana. A vinda à Bahia, em maio de 1941, do renomado urbanista francês Alfred Agache - colaborador da Coimbra Bueno - foi amplamente noticiada pela imprensa local e teve como objetivo a coleta de informações para a elaboração de uma proposta de trabalho daquela empresa.

Entretanto, antes que o contrato entre a Prefeitura de Salvador e a Coimbra Bueno fosse assinado, o engenheiro baiano Mário Leal Ferreira, detentor de vasta experiência em diversas áreas afins ao planejamento urbano - principalmente engenharia sanitária e sociologia -, encaminhou, em julho de 1942, uma proposta de trabalho à Prefeitura. Os técnicos da Prefeitura de Salvador recomendaram ao Prefeito Durval Neves da Rocha que optasse pela proposta de Mário Leal Ferreira, o que foi feito; o contrato, com duração de três anos, foi assinado em 03 de novembro daquele ano. Embora previsse que os trabalhos fossem iniciados já a partir de janeiro de 1943, o Escritório do Plano de Urbanismo da Cidade do Salvador (EPUCS) só começou a funcionar efetivamente três meses depois, em abril (SALVADOR, 1976, p. 23-25).

Após um ano e meio de trabalho, uma questão legal ${ }^{3}$ levou à constituição da Sociedade Escritório de Urbanística Ltda. que, representada pelo seu sócio Mário Leal Ferreira e pelo seu gerente Diógenes Rebouças, passa a ser a responsável legal pelo contrato para elaboração do Plano Urbanístico da Cidade do Salvador.

\footnotetext{
${ }^{2}$ Diógenes de Almeida Rebouças nasceu em 1914 em uma fazenda no município baiano de Amargosa e, aos quatro anos, se transferiu com a família para Itabuna, na região cacaueira do estado, onde os pais possuíam propriedades rurais. Aos 16 anos matriculou-se no curso de Engenharia Agrônomica da Escola Agrícola da Bahia, em São Bento das Lajes, município de São Francisco do Conde, próximo a Salvador. Concluído o curso em 1933, retorna a Itabuna, onde começa a trabalhar como topógrafo para a Prefeitura, ao mesmo tempo em que ajuda a administrar as fazendas de cacau da família. Através dos contatos sociais da família e dos engenheiros que conheceu como topógrafo em Itabuna, passa a fazer projetos de arquitetura, se tornando um dos mais produtivos projetistas da cidade nos anos 30 . Em 1936, Diógenes Rebouças transfere-se para Salvador, onde havia iniciado cinco anos antes os cursos de arquitetura e pintura na Escola de Belas-Artes da Bahia, que, contudo, pouco frequentava. Em 1937, diploma-se com o título de Professor de Desenho e Pintura. Rebouças só receberia o título de arquiteto em 1952, quando já era o mais importante arquiteto baiano há anos.

3 Após o Prefeito Elísio Lisboa e o Departamento Administrativo da Prefeitura levantarem a questão da ilegalidade da acumulação de dois cargos públicos por Mario Leal Ferreira - que já era, à época da assinatura do contrato, professor da Escola Nacional de Belas Artes -, a Procuradoria Jurídica do Município entendeu que, de fato, havia uma incompatibilidade legal (SALVADOR, 1976, p. 25).
} 
Os exaustivos trabalhos de pesquisa, levantamento de dados e definição de diretrizes para os principais problemas de Salvador não foram entregues no prazo originalmente previsto no contrato, e este foi sucessivamente aditado. Entretanto, em 11 de março de 1947, subitamente, Ferreira falece. Diógenes Rebouças assume então a direção dos trabalhos e reúne, no Rio de Janeiro, os diversos estudos existentes no escritório de Ferreira, para trazê-los a Salvador ${ }^{4}$.

Nos seus primeiros anos de funcionamento, sob a coordenação de Mário Leal Ferreira, o EPUCS elaborou uma série de estudos aprofundados em diversas áreas. Além do levantamento aerofotogramétrico da zona urbana de Salvador e de um conjunto de pesquisas históricas visando constituir a "enciclopédia urbanística da Cidade do Salvador", o EPUCS realizou investigações sobre uma série de temas: condições do meio físico, compreendendo geologia, topografia, meteorologia e climatologia; arquitetura e estética urbana; higiene e saneamento da habitação e das zonas urbanas; redes de infraestrutura urbana; abastecimento alimentar, inclusive relacionando-o com a produção agrícola e industrial na zona urbana e nos subúrbios; educação e cultura, incluindo religião, esportes e artes recreativas, diversões, cultura social, artística e literária; e, por fim, finanças, economia urbana e legislação urbanística. Esses levantamentos subsidiaram as propostas do plano, dentre as quais estavam a diferenciação de zonas; a definição de vias de comunicação, de áreas destinadas a parques e jardins e de zonas de habitações; a localização dos diversos

\footnotetext{
${ }^{4}$ Oficialmente, o EPUCS encerrou suas atividades logo após o falecimento de Mario Leal Ferreira e, a partir do decreto assinado pelo Prefeito Wanderley Pinho em 29 de janeiro de 1948, foi criada a Comissão do Plano de Urbanismo da Cidade do Salvador (CPUCS) para dar continuidade às ações iniciadas pelo EPUCS. Entretanto, a imprensa local e mesmo os relatórios do Prefeito Wanderley Pinho continuaram a se referir ao EPUCS - e jamais à CPUCS - nas matérias publicadas pelos cinco anos que se seguiram à sua extinção; mesmo hoje, passados mais de 60 anos da mudança, todos os ex colaboradores do EPUCS que entrevistamos - inclusive aqueles que ingressaram na estrutura após 1947 - jamais se referem à CPUCS e usam sempre a sigla EPUCS. Uma matéria do vespertino $A$ Tarde, por exemplo, informava que, no dia 04 de fevereiro de 1950, "o governador [Otávio Mangabeira] chegava ao Epucs" em companhia do Diretor do Departamento Nacional de Obras de Saneamento e de outras autoridades, para discutir as obras de saneamento em andamento, à época, no rio Camarogipe (COMEÇOU..., 1950, p. 02). Também em fevereiro de 1950, o governador, o secretário do Interior do Estado e o diretor da Penitenciária do Estado se reuniram com "Diógenes Rebouças e João Augusto Calmon, do Epucs, para o fim de examinar o ante-projeto, por este elaborado, da nova Penitenciaria, que o governo do Estado vai fazer construir" (A BAHIA TERÁ..., 1950, p. 02). Em abril de 1952, um consultor técnico da Fundação da Casa Popular (FCP), órgão então responsável pela política nacional de habitação de interesse social, sediado na Capital Federal, veio a Salvador e se reuniu "no EPUCS, com o prefeito e alguns técnicos", no intuito de estabelecer um plano de atuação para a FCP na Bahia (CASAS POPULARES..., 1952, p. 02). Da mesma forma, as matérias publicadas nos jornais locais após a morte de Ferreira também costumavam apresentar Diógenes Rebouças como "o Diretor do EPUCS" (p. ex., VILA..., 1947, p. 01; CONTINUIDADE..., 1949, p. 02; O HOTEL SERVIRÁ..., 1950, p. 02) e, ao que tudo indica, o EPUCS continuou a funcionar no mesmo local em que funcionava à época de Ferreira - o terceiro andar do sobrado azulejado da Praça Cairú, no Comércio - pelo menos até junho de 1949, quando se viu ameaçado de despejo em função da venda do imóvel (O E.P.U.C.S...., 1949, p. 02). Por essas razões, ao longo deste trabalho, nos referiremos sempre ao EPUCS, mesmo quando abordarmos as ações levadas a cabo após o falecimento de Ferreira e a extinção oficial - mas não real - daquela estrutura.
}

URBANA, V.5, n6, mar.2013 - Dossiê: Urbanistas e Urbanismo- CIEC/UNICAMP 
serviços públicos, bem como de Centros Cívicos de alcance local e urbano e de centros de abastecimento (SALVADOR, 1976, p. 39) ${ }^{5}$.

O EPUCS concebeu a cidade "como algo 'evolutivo', enfatizando a história e a morfologia do sítio como elementos-chave para corrigir as 'distorções e deformações' observadas no meio social e econômico" (FERNANDES, GOMES \& SAMPAIO, 1999, p. 412). A partir do entendimento geomorfológico de Salvador e da ocupação histórica que privilegiara o topo dos morros, o EPUCS identificou e adotou um sistema radioconcêntrico de ocupação, com vias radiais ligando os bairros ao centro e vias concêntricas fazendo as ligações bairro-bairro (FIGURA 03). Eram previstas ainda a articulação entre cumeadas e vales; a separação do tráfego por modos de circulação que incluíam os automóveis, os bondes e os pedestres; e a criação de vias de tráfego rápido nos vales da cidade, então livres.

As avenidas de vale serão, certamente, o aspecto mais conhecido do plano do EPUCS, uma vez que a primeira delas - a Avenida do Centenário - começou a ser implantada em 1949, como parte das comemorações do 40 centenário de fundação de Salvador, a partir de traçado definido pelo próprio Diógenes Rebouças ${ }^{6}$.

Também a partir da geomorfologia do sítio, o EPUCS identifica um conjunto de altiplanos, que são associados à figura de um trevo de quatro folhas, tendo ao centro áreas relativamente planas, nas quais são propostos "centros cívicos", onde seriam concentrados os bens e serviços de consumo diário, como comércio, higiene, assistência e segurança (SAMPAIO, 1999, p. 208) (FIGURA 04). Os 19 "centros cívicos" identificados pelo plano do EPUCS em Salvador deveriam funcionar como "centros catalizadores [sic] das atividades sociais" da população residente nos altiplanos vizinhos - as "folhas" do trevo" - ou nas encostas dos pequenos vales e grotões do entorno (SALVADOR, 1976, p. 79-80)

\footnotetext{
${ }^{5}$ Não está entre os objetivos deste trabalho proceder a uma análise do plano elaborado pelo EPUCS. Sobre o plano do EPUCS, o que nos parece importante aqui é apresentar, em termos gerais, em que consistiu e quais suas consequências reais sobre a transformação espacial de Salvador, através da literatura existente sobre o assunto (SALVADOR, 1976; BRUAND, 1981; ARAÚJO, 1992; SANTOS NETO, 1993; SAMPAIO, 1999; FERNANDES, GOMES \& SAMPAIO, 1999; GARZEDIN, 2004; FERNANDES, 2008) ainda que esta seja revisada criticamente em alguns aspectos fundamentais e identifiquemos algumas dissonâncias entre o relato consagrado e os documentos que localizamos, como, por exemplo, com relação à sobrevida e aos caminhos do EPUCS sob o comando de Rebouças, após a morte de Ferreira. A nossa contribuição consistirá, portanto, em identificar e analisar o papel do EPUCS como escritório estatal de projetos de arquitetura e urbanismo, e a sua contribuição à consolidação da arquitetura moderna na Bahia e à formação de uma geração de arquitetos e urbanistas locais.

${ }^{6}$ A notoriedade do sistema de avenidas de vale proposto pelo EPUCS resulta também do fato de que, por muitas décadas, o poder público continuaria a considerar a sua implantação como uma prioridade, executando, assim, uma série de obras nesse sentido. Entretanto, Heliodório Sampaio ressalta que "a única via de vale implementada, que de fato espelha a concepção do EPUCS, corresponde ao trecho da Av. Centenário, entre o túnel e o Chame-Chame. As demais, do período pós-64 [...], não tiveram projetos executivos dentro dos princípios e parâmetros do plano" (SAMPAIO, 1999, p. 217).
} 

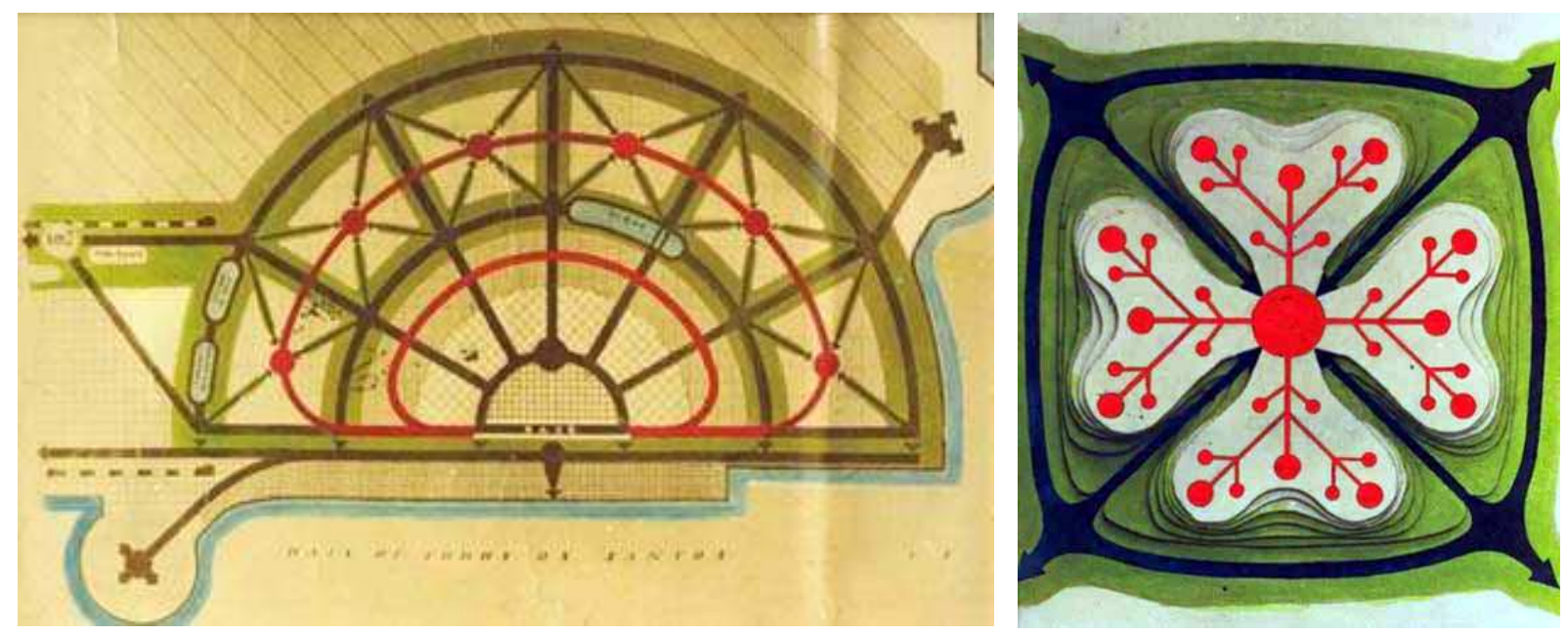

Figuras 03 e 04: EPUCS: sistema radioconcêntrico da cidade (à esquerda) e esquema das unidades de vizinhança, em formato de "trevo de quatro folhas" (à direita) (Fontes: CEAB/FAUFBA; www.urbanismobr.org)

Outra questão inovadora do EPUCS correspondia à preocupação com o problema da habitação proletária, ao defender que o Estado deveria intervir diretamente na solução dessa questão, através da aquisição de terras visando subsidiar a moradia popular e regular o mercado. Segundo Heliodório Sampaio (1999, p. 210), "o EPUCS [...] aproxima-se pragmaticamente dos problemas da habitação de interesse social".

A equipe que compunha o EPUCS era extensa e formada por engenheiros, arquitetos, advogado, historiadores, médicos, arquivistas, desenhistas, topógrafos e maquetistas, além de contar com um corpo administrativo e colaboradores em diversas especialidades, como botânica, geografia, saúde, materiais de construção e museus. Nesses primeiros quatro anos do EPUCS, cabia a Diógenes Rebouças "compatibilizar a concepção espacial do modelo adotado aos 'princípios gerais', submetendo a proposta física à coordenação geral de Mário Leal" (SAMPAIO, 1999, p. 198),

Além dos recursos humanos, a infraestrutura também era completa: segundo Guarani Araripe, que trabalhou como desenhista do EPUCS em 1945, "era o mais avançado escritório de engenharia do Brasil. Um equipamento de desenho ou levantamento que fosse lançado à época na Alemanha, por exemplo, era imediatamente comprado pelo EPUCS"7.

Para Heliodório Sampaio, Mário Leal Ferreira possuía uma visão ampla da complexidade que envolve o planejamento urbano, adquirida "de sua formação no

\footnotetext{
${ }^{7}$ Entrevista concedida ao autor em 21 de outubro de 2010.

URBANA, V.5, n6, mar.2013 - Dossiê: Urbanistas e Urbanismo- CIEC/UNICAMP
} 
exterior" e que estava "muito distante da utopia lecorbusiana e sua visão simplificada e pouco abrangente do que era a cidade-ideal, no geral reduzida a habitar, trabalhar, recrear e circular, como elementos estruturantes do processo", bem como dos CIAM, estando mais próximo da vertente teórica comprehensive planning (SAMPAIO, 1999, p. 198).

O EPUCS se transformou em uma referência em análise e planejamento urbano moderno em todo o Brasil. Já em 1946, o engenheiro-arquiteto paulista Eduardo Kneese de Mello, após realizar uma visita a Salvador, publicou na revista Acrópole a transcrição de uma palestra sobre as suas "Impressões de uma viagem á Baia". Após se deter longamente sobre "as tradições da cidade do Salvador, seus aspectos típicos", as igrejas e fortificações coloniais, as praias, o candomblé, "a deliciosa comida baiana, os costumes, a maneira de falar", a "gente fina, amavel e hospitaleira" e "a beleza das moças baianas", Kneese de Mello destaca "duas cousas na Baia, que desejo apresentar aos paulistas, como merecedoras de nosso especial aplauso. Dois exemplos que merecem ser seguidos" (MELLO, 1946, p. 317-320). O primeiro desses exemplos é a vila operária, incluindo uma série de pequenos estabelecimentos comerciais e de serviços, que o industrial Luiz Tarquinio idealizara e construíra junto à sua fábrica, em 1892. O segundo é "o Escritorio da Plano de Urbanisação da Cidade do Salvador, conhecido pelas iniciais EPUCS" [sic], sobre o qual Kneese de Mello só tem palavras elogiosas:

São Paulo se orgulha de ser a cidade que mais constróe em todo o mundo. É também o maior centro industrial da America do Sul. Sua população cresce fantasticamente atingido [sic] já perto dos dois milhões de habitantes.

No entanto, São Paulo não tem um plano direto [sic] para o seu crescimento. A cidade se expande para o lado que quer e as residências se misturam com as fabricas e os arranha-ceus fazem sombra às casas terreas.

- A Baía é uma cidade pequena [...]. Sua população é de 350 mil habitantes, Menos de um quinto da de São Paulo. A Baia não é uma cidade industrial e não constróe 5 casas por hora, como São Paulo.

No entanto, a Baia já está fazendo seu plano diretor. Está procurando evitar um crescimento errado que amanhã resulte em grandes males para a coletividade, males que muitas vezes são irreparaveis.

A Baia não está alargando ruas apenas, como o fazem muitas outras cidades brasileiras, sob o título de urbanismo. A Baia está estudando seu plano de verdade. Baseado em inqueritos cuidadosos da população, suas condições de vida, tipo e trabalho, mortalidade infantil, molestias em geral, possibilidades economicas. Serviço que vem durando anos. Feito de porta em porta. 25.000 inqueritos já prontos.

O plano futuro da Baia será baseado, no rigoroso levantamento topografico da região, no estudado fornecimento e escoamento das aguas, no estudo do trafego, no aproveitamento dos parques e bosques naturaes, na conservação de monumentos históricos e artísticos, no zoneamento, na distribuição 
proporcional de escolas, hospitaes, play-grounds. O plano diretor da Baia será baseado, enfim, no conhecimento completo de suas condições atuais e de suas possibilidades futuras.

Com esses dados em mãos, o urbanista poderá traçar com segurança as diretrizes do desenvolvimento urbano e a Baia será então uma das mais lindas cidades da America (MELLO, 1946, p. 320).

Somente em março de 1948 entrou em vigor a primeira lei urbanística voltada a oficializar as diretrizes do EPUCS: o Decreto-lei no 701, de 24 de março de 1948, que "dispõe sobre a divisão e utilização da terra na Zona Urbana da Cidade, regula o loteamento de terrenos na mesma Zona situados e dá outras providências" (apud ARAÚJO, 1992, p.284). Este decreto-lei dividia a cidade em 12 setores: um Central, um Portuário e Comercial, um Industrial, sete setores Residenciais e dois de Transição. Embora tenha subdivido o território em zonas de uso, o Decreto-Lei no 701/48 não estabelecia ainda as respectivas restrições de ocupação.

O estabelecimento de gabaritos máximos de altura e de outros parâmetros urbanísticos para os diversos setores de Salvador, contudo, só ocorreu seis anos depois, com a entrada em vigor do Decreto no 1.335 , de $1^{\circ}$ de janeiro de 1954 , que "regulamenta normas para a fixação de gabaritos de altura da Cidade de Salvador" (apud ARAÚJO, 1992, p. 342). Dentre outros aspectos, esse decreto determinou que, no bairro do Comércio, na Cidade Baixa (Setor Portuário e Comercial), cada nova edificação possuísse "galeria pública obrigatória, recuada de 4,00 m, fachada escalonada em planos, o da galeria e, acima desta, avançando em balanço $(0,50 \mathrm{~m})$ sobre a via pública, recuando depois para o mesmo plano da galeria", bem como definiu como alturas máximas 11,00 metros (para o teto da galeria), 38,00 metros (teto do último pavimento em balanço) e 45,00 metros (teto da edificação) e definiu uma taxa de ocupação de 90\% (ARAújo, 1992, QV 1).

No bairro do Comércio, predominavam até então as edificações ecléticas construídas entre as últimas décadas do século XIX e as primeiras décadas do século XX em estrutura mural e possuindo um máximo de quatro ou cinco pavimentos, e mesmo as construções modernas, erguidas com estrutura de concreto armado na década de 1930 e claramente influenciadas pela Bauhaus, como o já citado Instituto do Cacau e a Agência Central dos Correios e Telégrafos, mantinham esse gabarito e as fachadas predominantemente maciças, destoando da sua verdadeira natureza estrutural. A nova visão urbanística e paisagística implementada pelo Decreto-Lei Municipal no 701/48 e pelo Decreto no $1.335 / 54$ promoveram o surgimento de uma nova arquitetura no bairro, caracterizada por torres de escritórios de até 12 pavimentos, erguidas sobre pilotis que permitiam a criação de uma galeria pública 
com quatro metros de largura no nível da rua. Parâmetros análogos são estabelecidos para o setor comercial da Cidade Alta, formado pela Avenida Sete de Setembro e pelas Ruas da Ajuda, Chile e Carlos Gomes. Segundo Aruane Garzedin,

Essa solução de projeto urbano surge em Salvador, em um contexto de verticalização das construções e de adoção do sistema construtivo facilitado pela tecnologia do concreto armado, que possibilitava o térreo vazado, sem comprometimento do espaço por espessas paredes. Essa solução [...] representa uma iniciativa de desenho urbano que objetiva resolver questões de circulação de pedestres e, ao mesmo tempo, melhorar a qualidade visual da rua. Resolvia, no âmbito da arquitetura da edificação, a proteção dos pedestres do sol e da chuva, que os toldos e outros artifícios como marquises de concreto, usados como apêndices nas fachadas, tentavam minimizar (GARZEDIN, 2004, p. 268)

Em alguns setores do Comércio, como no trecho da Rua Miguel Calmon situado entre a Praça Riachuelo e a Praça Marechal Deodoro, o respeito aos parâmetros estabelecidos pelo EPUCS resultou, em longo prazo, em um conjunto arquitetônico que oferece uma larga galeria coberta e contínua, aberta ao uso público, embora cada edifício adote soluções estruturais e, principalmente, de fachada bastante distintas (FIGURA 05).

No caso de trechos urbanos em que alguns terrenos já haviam sido ocupados antes da entrada em vigor da lei, como em trechos da Avenida Sete de Setembro, na Cidade Alta, a sua aplicação resultou na descontinuidade provocada entre construções mais antigas, erguidas na testada do lote, sem recuo, e outras, alternadas, que generosamente ofereciam esses passeios cobertos à cidade, inviabilizando o objetivo final de criação de uma galeria coberta contínua.

O gabarito máximo de 45 metros para o bairro do Comércio, estabelecido pelo Decreto no 1.335/54, garantiu a preservação do frontispício de Salvador e da encosta verde, fundamentais na caracterização de um núcleo urbano formado por duas "Cidades" (Alta e Baixa) separadas por uma escarpa de 60 metros de altura, assim como viabilizou a manutenção das relações visuais entre a Cidade Alta e a Baía de Todos os Santos. As ações do EPUCS foram amplamente elogiadas por Yves Bruand, que destaca justamente essa preocupação em equacionar os conflitos entre a iminente verticalização do novo aterro do Comércio e a preservação dos valores paisagísticos de Salvador:

A conservação dos monumentos e bairros antigos [defendida pelo EPUCS] não foi concebida como uma manutenção estática da cidade no estado em que se achava, com uma proibição absoluta de se fazer a menor modificação. Uma das primeiras decisões tomadas foi, pelo contrário, estabelecer uma distinção entre os verdadeiros valores históricos que teriam direito a uma proteção total e as construções ou locais simplesmente pitorescos que não se vacilaria em destruir 
sempre que fosse necessário, quer por razões de higiene, quer por comodidade urbana, pela estética ou qualquer outro motivo. Essa atitude era lógica e digna de um urbanismo conservador bem compreendido, isento das nostalgias românticas dos amadores de casebres e ruínas para quem a miséria não passa de um tema para poesia. (...) A aplicação dessas idéias foi mais delicada do que sua enunciação e foi preciso passar pela prova de fogo perante as pressões de todo gênero que surgiram. Tentar evitar os edifícios de vários andares no centro comercial, que, desde o começo do século XIX, tinha sido transferido para a parte baixa da aglomeração, ao longo do porto, teria sido estranhamente parecido com a luta de Dom Quixote contra os moinhos; não se correu esse risco e defendeu-se apenas o que não era suscetível de compromissos: as igrejas coloniais, o edifício da Associação Comercial (...) bem como a maioria das construções originais dessa zona (...); houve uma preocupação com a preservação não só das obras em si, mas também dos espaços livres nas imediações (combate difícil em qualquer tempo), e principalmente limitou-se a altura dos arranha-céus num nível que permitia não tapar inapelavelmente a magnífica vista para a Baía que se tinha da cidade alta, munida de praças-belvederes únicas no país. (BRUAND, 1981, p. 342)

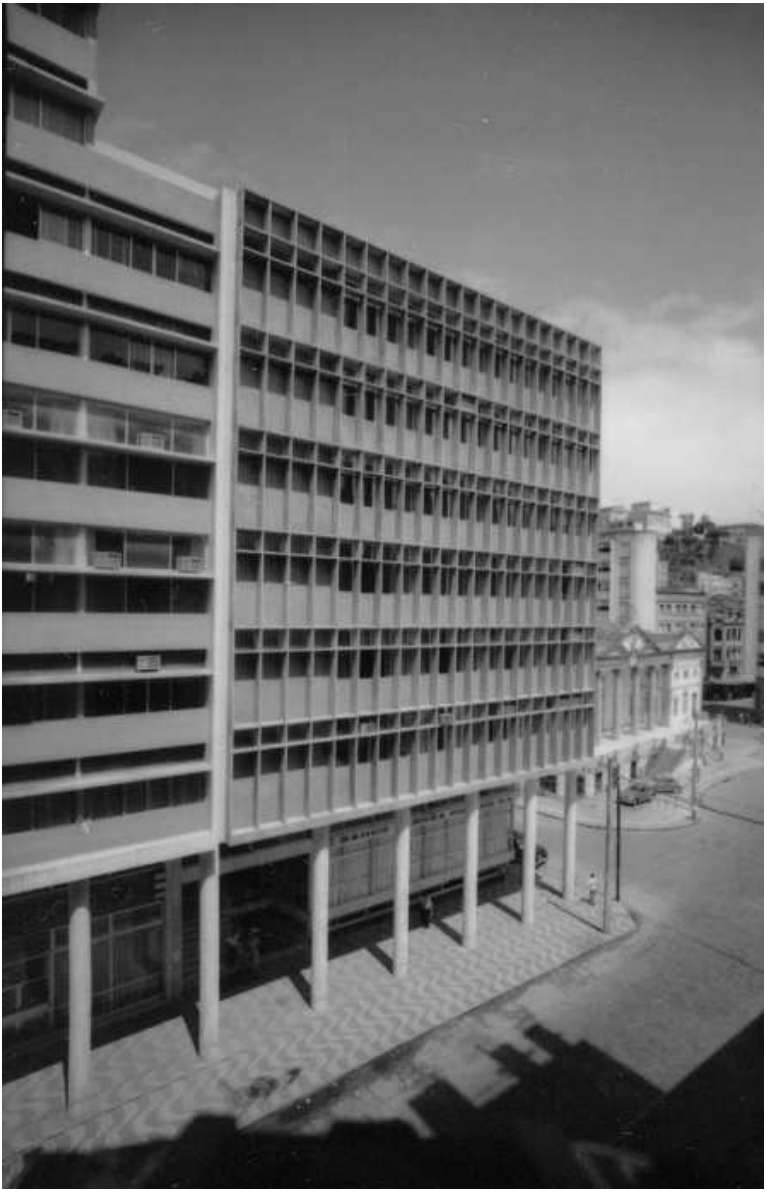

Figura 05: Edifícios construídos no bairro do Comércio entre o final dos anos 1950 e início dos 1960: blocos sobre pilotis, com criação de galerias cobertas, de acordo com as diretrizes do EPUCS e a legislação urbana delas decorrente - à esquerda, Edifício Ouro Preto, à direita, Edifício Almirante Barroso, ambos projetados por Diógenes Rebouças.

Fonte: Centro de Documentação e Referência da Odebrecht.

Entretanto, o EPUCS não foi somente alvo de elogios, mas também de críticas. A partir da entrada em vigor da legislação derivada dos estudos e diretrizes do EPUCS, estas críticas começaram a surgir com maior intensidade. Em matéria publicada em agosto de 1950 sobre o crescimento acelerado que Salvador vivera no último decênio, o jornal $A$ Tarde informava que, após registrar um recorde no número de construções erguidas na cidade em 1947, houve uma queda no ano de 1948. A 
matéria deixa subentendido que a culpa dessa desaceleração no mercado da construção decorria da "nova orientação ao sistema de licenças", que "complicou [...] mais ainda a já complicada burocracia, dificultando-se, assim, o desenvolvimento da cidade" (O CRESCIMENTO..., 1950, p. 02).

Críticas semelhantes, em que o EPUCS é acusado de atrapalhar a construção civil e o desenvolvimento urbano, foram feitas em matérias publicadas pelo mesmo periódico no ano seguinte, agora argumentando que o Instituto de Aposentadoria e Pensões dos Industriários (IAPI) tinha desistido de construir a sede da sua delegacia local em um terreno de sua propriedade localizado na rua Padre Vieira, no centro de Salvador, "em virtude das dificuldades criadas pelo Epucs" (O QUE FAZEM..., 1951, p. 02). A mesma matéria alega ainda que o Instituto de Aposentadoria e Pensões dos Comerciários (IAPC) também vinha encontrando dificuldades para construir conjuntos habitacionais para seus associados nos diversos terrenos que possuía em Salvador:

Apesar de tanto terreno vago, o I.A.P.C. construiu até agora apenas trezentas e poucas residencias que já se acham habitadas. Ao que se sabe, o numero de construções não é mais elevado por dois motivos: algumas obras marcham lentamente dada a excessiva burocracia do EPUCS, no traçar os planos de urbanização e falta de recursos necessários por parte do Instituto para construir edifícios em todos os terrenos de sua propriedade (O QUE FAZEM..., 1951, p. 04).

Apesar dessas críticas, o EPUCS representou uma contribuição fundamental ao processo de planejamento de Salvador e, de certa forma, uma experiência pioneira no panorama do planejamento urbano brasileiro. Sobre o progressivo abandono do plano do EPUCS nas décadas seguintes, Heliodório Sampaio observa que

[...] o caráter enfitêutico da posse e uso da terra, por um lado, e a crescente debilidade do governo municipal no enfrentamento da questão, bem como sua incapacidade de obter os investimentos necessários à infra-estruturação preconizada por Mário Leal e sua equipe (redes de água, esgotos sanitários, vias primárias e secundárias, educação, saúde, habitação, áreas verdes e recreação, etc.) acabam 'congelando' as grandes diretrizes do Plano na sua dimensão social, reduzindo-o, nos anos seguintes, às questões viárias, dando suporte ao rodoviarismo pós-64 no urbano (SAMPAIO, 1999, p. 105).

A contribuição do EPUCS à consolidação da arquitetura moderna na Bahia e à autonomização do campo arquitetônico no Estado se dará, eminentemente, em sua segunda fase (1947-1950), quando, após a morte de Mário Leal Ferreira, Diógenes Rebouças assumiu a sua direção e Ihe imprimiu novos rumos, agregando às suas atribuições a elaboração de uma série de projetos arquitetônicos e urbanísticos de interesse público ${ }^{8}$.

\footnotetext{
${ }^{8}$ Ainda que, já em 1942 - antes mesmo da efetiva implantação do EPUCS -, Diógenes Rebouças e Mário Leal Ferreira tenham dado uma primeira grande contribuição à arquitetura moderna na Bahia, através do URBANA, V.5, n6, mar.2013 - Dossiê: Urbanistas e Urbanismo- CIEC/UNICAMP
} 


\section{Diógenes Rebouças, o EPUCS e a consolidação da arquitetura moderna na Bahia}

Segundo os autores do mais completo levantamento, até hoje, da atuação do EPUCS $^{9}$, nos anos que se seguiram à morte de Mário Leal Ferreira, em 1947, o EPUCS, "distanciava-se cada vez mais daquela que seria a sua atribuição principal, isto é, continuar o processo de planejamento em seu sentido mais amplo" e "limitava-se a [...] dar pareceres em processos que the eram encaminhados e que implicavam na confecção de estudos, desenhos e gráficos" (SALVADOR, 1976, p. 30). Além disso, o EPUCS passou a elaborar uma série de projetos arquitetônicos e urbanísticos:

Embora oficialmente criada em 1948, até meados de 1950 a CPUCS não tinha sido ainda estruturada, funcionando, durante este período, precariamente, com o pessoal remanescente do EPUCS e sob a direção do arquiteto Diógenes Rebouças. Ainda durante este período, [...] foram [...] realizados, entre outros, os seguintes trabalhos: Projeto para o Centro Educacional Carneiro Ribeiro, Projeto para o Centro Educativo de Arte Teatral no Largo 2 de Julho, Planejamento da Urbanização dos povoados de Paripe e Itapoan e Projeto da Avenida Centenário, cujas obras foram oficialmente iniciadas em 29 de março de 1949, data em que se comemorou o IV Centenário da Cidade do Salvador (SALVADOR, 1976, p. 30).

Desta forma, no período em que esteve sob a direção de Diógenes Rebouças, entre 1947 e $1950^{10}$, o EPUCS se constituiu em um verdadeiro escritório de arquitetura e urbanismo, responsável pela elaboração direta dos principais projetos demandados não só pela Prefeitura - à qual o EPUCS estava diretamente vinculado mas também pelo Governo do Estado, além de prestar assessoria a diversos órgãos e repartições do Governo Federal na execução de outros tantos projetos e ações.

O relatório apresentado pelo Prefeito Wanderley Pinho à Câmara de Vereadores em 07 de abril de 1949 sobre as ações desenvolvidas pela Prefeitura de Salvador no ano anterior confirma essa afirmação. Nele, o Prefeito registra que "o Escritório do Plano de Urbanismo da Cidade do Salvador continua a prestar seus serviços, com os mesmos elementos que encontrei", e apresenta uma lista de duas páginas enumerando os trabalhos desenvolvidos pelo EPUCS ao longo de 1948 (SALVADOR, 1949, p. 37-39).

projeto da Praça de Esportes da Bahia (Complexo Esportivo da Fonte Nova), cuja primeira etapa correspondeu à construção do estádio que seria batizado com o nome do governador Otávio Mangabeira. ${ }^{9}$ Estamos nos referindo à equipe do Órgão Central de Planejamento da Prefeitura Municipal de Salvador (OCEPLAN), coordenada pela arquiteta Terezinha Rios, que, em 1976, por ocasião da finalização do Plano de Desenvolvimento Urbano de Salvador (PLANDURB), publicou o livro EPUCS - uma experiência de planejamento urbano (SALVADOR, 1976).

${ }^{10}$ Segundo Heliodório Sampaio (1999, p. 214), Diógenes Rebouças dirigiu o CPUCS até 1950, quando foi substituído pelo engenheiro João Augusto Calmon; a partir de julho de 1951, este último seria substituído pelo também engenheiro Gustavo Maia.

URBANA, V.5, n6, mar.2013 - Dossiê: Urbanistas e Urbanismo- CIEC/UNICAMP 
A lista apresentada pelo Prefeito se divide em três tipos de atividades; a mais curta é a dos "serviços de rotina", com apenas quatro itens, e que corresponde às "atividades que constituem a própria finalidade do Escritório". Por um lado, a elaboração de "estudos e sugestões para loteamento e reestruturação de quadras" e o "fornecimento [...] de elementos e dados para informação de processos pela D.U.C.P. [Diretoria de Urbanismo e Cadastro da Prefeitura]" visavam suprir as demandas diretas da Prefeitura e da população relativas à aprovação de projetos, frente à ausência, à época, de uma legislação que definisse com clareza todos os parâmetros estabelecidos pelo EPUCS para o uso e a ocupação do solo ${ }^{11}$. Por outro lado, o EPUCS atualizava e finalizava os levantamentos e estudos previstos no escopo original do contrato assinado com a Prefeitura, com ações como a "continuação dos trabalhos de ajustamento de plantas, esquemas, esboços e ante-projetos realizados aos elementos da Planta Cadastral Aerofotogramétrica, fornecida pela Cia. 'Serviços Aéreos Cruzeiro do Sul'" e a "renovação e atualização de plantas, esquemas e maquetes que constituem o documentário do Escritório" (SALVADOR, 1949, p. 38).

Entretanto, o que chama a atenção na lista de atividades do EPUCS em 1948 é que, muito mais do que os "serviços de rotina", a sua equipe estava dedicada à realização do que se denominou de "outros serviços" e de "encargos especiais". Os "outros serviços" listados correspondiam a cinco "trabalhos de cooperação com repartições federais e estaduais" e incluíam desde a assessoria em projetos de saneamento urbano ${ }^{12}$ até uma série de estudos em parceria com a Universidade da Bahia. No caso da parceria com a Universidade, os serviços correspondiam ao "planejamento do ajardinamento dos terrenos adjacentes ao Hospital das Clínicas, estudos de localização dos pavilhões da Maternidade e da Clínica Tisiológica do mesmo Hospital" e ao "estudo de localização definitiva da Escola Politécnica, na Cidade Universitária da Boa-Vista, no sub-distrito de Brotas, com a necessária articulação dos arruamentos da mesma com o Sistema Viário Geral da Capital" $(\text { SALVADOR, 1949, p. 38) })^{13}$.

\footnotetext{
${ }^{11}$ Como vimos, somente a partir de 1954 , com a entrada em vigor do Decreto $\mathrm{n}^{\circ} 1.335$, os parâmetros urbanísticos estabelecidos a partir dos estudos do EPUCS começariam a ser regulamentados. Apesar da sua importância na divisão da cidade em setores, o Decreto-lei no 701, de 24 de março de 1948, não estabelecia ainda as respectivas restrições de ocupação.

12 Como o "desvio e canalização do rio Camorogipe" e a "retificação e estabelecimento dos talwgs [sic] dos rios das Tripas e Camorogipe", realizados em parceria com os Serviços Nacional de Saneamento e de Malária, respectivamente, dentre outros (SALVADOR, 1949, p. 38).

${ }^{13}$ A proposta de implantação da Cidade Universitária na Boa Vista de Brotas foi abortada e a região do Canela, onde já vinham sendo construídos os equipamentos universitários vinculados à área de saúde (Escola de Enfermagem, Hospital das Clínicas, Clínica Tisiológica e Maternidade) e onde, em 1952, foi inaugurado o Palácio da Reitoria, termina por se consolidar, neste período, como o "Centro
} 
Dois "outros serviços" foram realizados pelo EPUCS em 1948, em parceria com o Governo do Estado. Com a Secretaria de Viação e Obras Públicas, ele elaborou "os estudos preliminares para o projeto do Conjunto Educativo de Arte Teatral, ao Parque Dois de Julho [Campo Grande]" e forneceu "subsídios e sugestões aos arquitetos encarregados da execução do projeto", além de municiar os técnicos responsáveis pelo abastecimento de água e pelas estradas de rodagem de acesso a Salvador com uma série de informações sobre a cidade e as diretrizes estabelecidas no seu plano. Com a Secretaria de Educação e Saúde, o EPUCS procedeu à "escolha e localização definitiva dos terrenos destinados às escolas-classe do Centro Educacional Carneiro Ribeiro, à Liberdade, com o estudo dos acessos ao mesmo Centro Educacional", aos "estudos de localização do Centro Educacional Secundário (Ginásio) do Garcia" e aos "estudos de localização e planejamento da Colônia de Psicopatas em Pedras Pretas" (SALVADOR, 1949, p. 37-38).

Dentre os "encargos especiais" desempenhados pelo EPUCS em 1948, por incumbência direta do Prefeito Wanderley Pinho, estavam a "assistência ao Dr. Roberto Burle Max [sic], facilitando-Ihe os dados e indicações necessários à elaboração dos projetos de remodelação dos jardins e parques da Cidade", a "elaboração do ante-projeto, com maquete, da remodelação do belvedere da Sé, para localização do Marco Comemorativo do IV Centenário da Fundação da Cidade", os "estudos de projeto e localização da Avenida do Centenário, compreendendo o projeto de drenagem das águas da bacia do Dique e riachos de S. Pedro, Chame-Chame e Calabar" e os "estudos de bases para o edital de concorrência pública para a construção do Túnel S. Miguel-Fonte Nova" (SALVADOR, 1949, p. 38).

Se, por um lado, era natural que o EPUCS ficasse responsável pelo assessoramento aos órgãos federais e estaduais nos assuntos relativos à infraestrutura urbana - como saneamento urbano, abastecimento de água e acesso rodoviário à cidade - e pela definição da localização de equipamentos de grande impacto sobre a estrutura urbana - como a Escola Politécnica, a Maternidade e a Clínica Tisiológica da Universidade da Bahia, a Colônia de Psicopatas e os diversos equipamentos escolares citados acima -, por outro é, no mínimo, inusitado que o escritório de planejamento urbano de Salvador assumisse a elaboração do projeto da

Universitário" da Universidade da Bahia, sendo objeto de uma série de estudos, à época, voltados ao planejamento da sua ocupação por parte dos arquitetos Wladimir Alves de Souza e Geraldo Câmara. A partir da segunda metade da década de 1950 começa a implantação de um segundo campus universitário, na Federação, através da construção da Escola Politécnica (1955-1960) e da Faculdade de Arquitetura (1964-1971); esse campus se amplia pelo bairro vizinho de Ondina, com a incorporação da Escola de Medicina Veterinária e do Hospital Veterinário já existentes.

URBANA, V.5, nº6, mar.2013 - Dossiê: Urbanistas e Urbanismo- CIEC/UNICAMP 
Avenida Contorno e, principalmente, do projeto paisagístico do entorno do Hospital das Clínicas, do estudo preliminar do Conjunto Educativo de Arte Teatral e do anteprojeto de remodelação do Belvedere da Sé. Além do mais, com relação ao Centro Educacional Carneiro Ribeiro - escolas-classe e Escola-Parque - e ao Ginásio do Garcia, o próprio Diógenes Rebouças, a convite de Anísio Teixeira, iria além da definição da localização desses equipamentos, ficando encarregado da elaboração dos respectivos projetos arquitetônicos nas próprias instalações do EPUCS $^{14}$.

Além dos projetos citados, foram desenvolvidos, no âmbito dessa estrutura remanescente do EPUCS, os projetos arquitetônicos do Hotel da Bahia (FIGURA 06), da Penitenciária do Estado e de uma série de escolas e complexos educacionais para Salvador e para o interior do Estado. Todos os projetos citados - com exceção do Centro Educativo de Arte Teatral (CEAT) - foram elaborados diretamente por Diógenes Rebouças para o Governo do Estado ${ }^{15}$.

No EPUCS, Rebouças elaborou ainda projetos para a Prefeitura de Salvador, como o mercado para venda de peixe junto ao Forte de Santa Maria, no bairro da Barra, e indicou a contratação de Roberto Burle Marx para elaborar projetos de três importantes praças centrais da cidade: a Piedade, o Campo Grande e o Terreiro de Jesus. Foi no âmbito do EPUCS, ainda, que se definiu a ampliação do Hospital Santa Terezinha e a consequente construção de uma série de pavilhões visando à sua ampliação, que viriam a constituir o Parque Sanatorial Otávio Mangabeira, sendo Rebouças responsável pela elaboração do projeto de alguns desses pavilhões.

\footnotetext{
${ }^{14}$ As nossas pesquisas indicam que, até 1952, quando estruturaria seu escritório privado de projetos, o único endereço comercial de Diógenes Rebouças era o EPUCS. O projeto do Hotel da Bahia, por exemplo, foi elaborado diretamente pelo EPUCS, a ponto de, quando da visita, em 1950 , de um repórter de $A$ Tarde às obras em execução do hotel, Rebouças tê-lo acompanhado até os escritórios do EPUCS, que, segundo o repórter, "para não perder muito tempo [estavam] localizados bem ali defronte"; no EPUCS estavam todas as plantas e desenhos do projeto do hotel (O HOTEL SERVIRÁ..., 1950, p. 2). Da mesma forma, quando Rodrigo Mello Franco de Andrade, Diretor do Serviço de Patrimônio Histórico e Artístico Nacional (SPHAN), escreveu para Rebouças, em julho de 1948, para solicitar informações sobre o projeto do Hotel de Paulo Afonso, então em etapa inicial de elaboração, ele endereça seu telegrama ao "Dr. Diógenes Rebouças - EPUCS - Praça Cairú - Salvador (Bahia)" (ANS/IPHAN-SO, Cx. 0020, P. 0088).

15 Após elaborar um estudo preliminar para o CEAT, Rebouças - sobrecarregado com outros projetos solicita a Lucio Costa que elabore o projeto definitivo; Costa, por sua vez, sugere os nomes de Alcides da Rocha Miranda e José de Souza Reis para assumir o encargo. No caso do Hotel da Bahia, um estudo foi elaborado inicialmente por Diógenes Rebouças, sendo posteriormente desenvolvido pelo arquiteto baiano em parceria com o arquiteto carioca Paulo Antunes Ribeiro. Os desenhos do que acreditamos seja esse primeiro estudo de Rebouças para o Hotel da Bahia encontram-se no acervo do EPUCS, na Fundação Gregório de Mattos, da Prefeitura Municipal de Salvador.
}

URBANA, V.5, n6, mar.2013 - Dossiê: Urbanistas e Urbanismo- CIEC/UNICAMP 


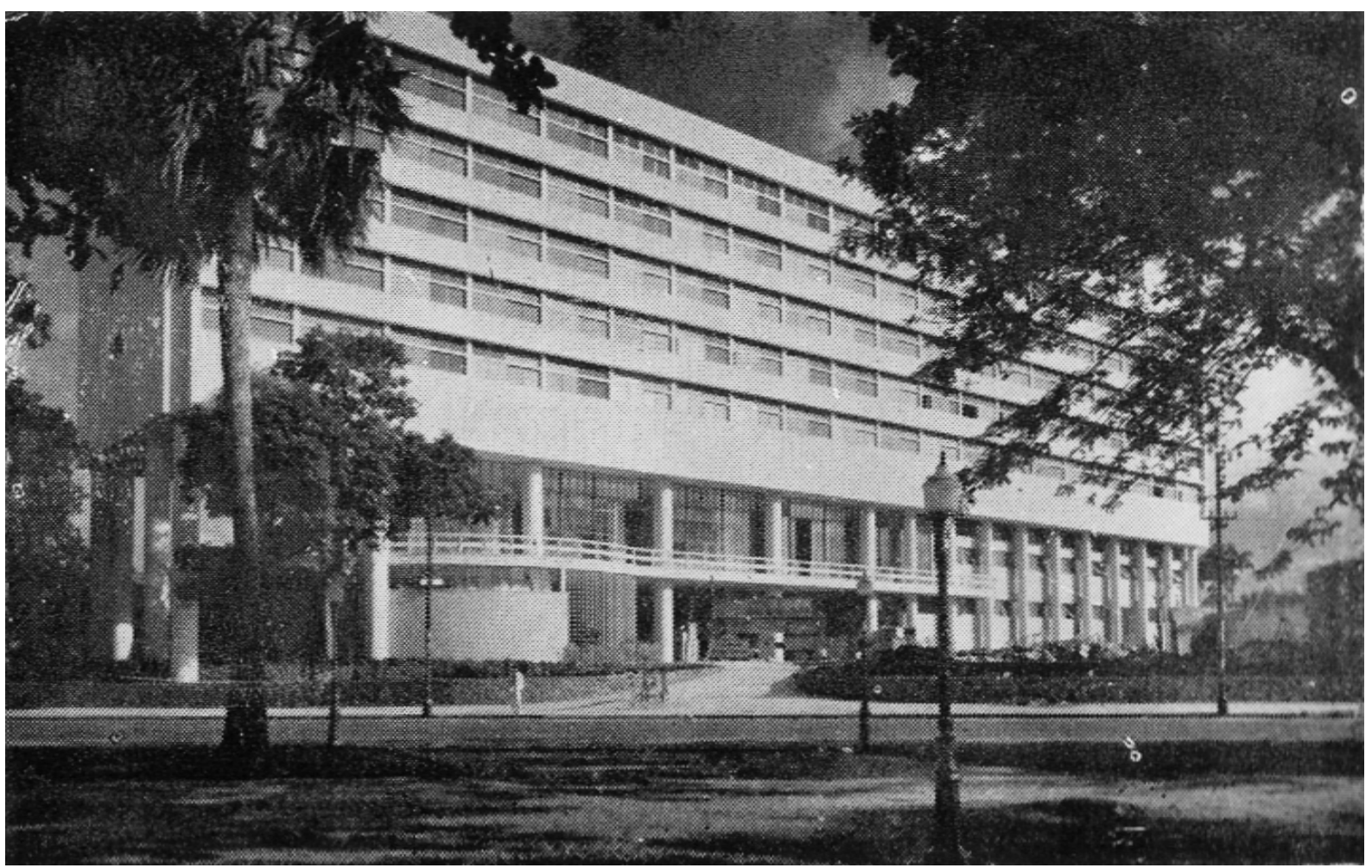

Figura 06: Hotel da Bahia já concluído.

Fonte: SALVADOR, 1951

Assim, entre 1947 e 1950, o EPUCS passa a acumular uma série de encargos não previstos no escopo original do contrato assinado com a Prefeitura, que darão ao seu diretor, o engenheiro agrônomo e licenciado em pintura e desenho Diógenes Rebouças, ampla visibilidade e grande reconhecimento, angariando capital simbólico ${ }^{16}$ e se transformando, desta forma, no mais importante e prolífico arquiteto baiano mesmo sem possuir a titulação exigida para exercer legalmente a profissão - até, pelo menos, a primeira metade dos anos 1960 quando uma geração de ex colaboradores do EPUCS e de ex alunos passará a dominar o mercado de trabalho e lhe reservará um papel cada vez mais secundário no campo arquitetônico baiano ${ }^{17}$.

\footnotetext{
16 "Capital simbólico" usado aqui no sentido definido por Pierre Bourdieu, isto é "todos os bens, materiais e simbólicos, sem distinção, que se apresentam como raros e merecedores de procura em uma formação social específica" (BOURDIEU, 1977, p. 178, tradução nossa).

17 Dentre os projetos elaborados por Rebouças no período que precedeu o seu ingresso no EPUCS, estão algumas obras financiadas pela "organização de senhoras de caridade" de Itabuna, à época presidida por sua mãe, como o Abrigo São Francisco de Assis (1936), uma construção térrea e simples com cobertura em telhas cerâmicas, e a Catedral de São José (1935-1936), uma arquitetura "bem pré-moderna", nas palavras do próprio Diógenes (REBOUÇAS, 1999, p. 117); algumas residências em Salvador, como a de Mirabeau Sampaio, no bairro da Barra (1937) e a de Edeládio Ribeiro, no bairro dos Barris (1938), além de outras em Itabuna nos anos 1930 e início dos anos 1940. No que se refere a obras de maior porte anteriores ao Estádio da Fonte Nova, pudemos identificar basicamente a sede da Associação Atlética da Bahia (1941) e o Mercado Municipal de Itabuna (1942). A produção dessa primeira fase da atuação de Rebouças como arquiteto ainda não foi sistematicamente identificada e analisada.
} 
A ampliação - ou poderíamos mesmo dizer alteração - das atribuições do EPUCS, transformado em um escritório de projetos arquitetônicos e urbanísticos, garantirá, também, a propagação e a consolidação, em Salvador, da arquitetura moderna que Diógenes Rebouças começava a adotar então, assim como terá um papel fundamental na difusão da arte moderna, frequentemente integrada a esta arquitetura. Esse processo terá até mesmo um alcance estadual, na medida em que Rebouças também elabora, dentro do EPUCS, os projetos para uma série de edifícios escolares a serem construídos no interior do Estado e do hospital e do hotel de Paulo Afonso (FIGURA 07), então uma localidade do município de Glória, junto à divisa da Bahia com Alagoas e Pernambuco e às margens do rio São Francisco.

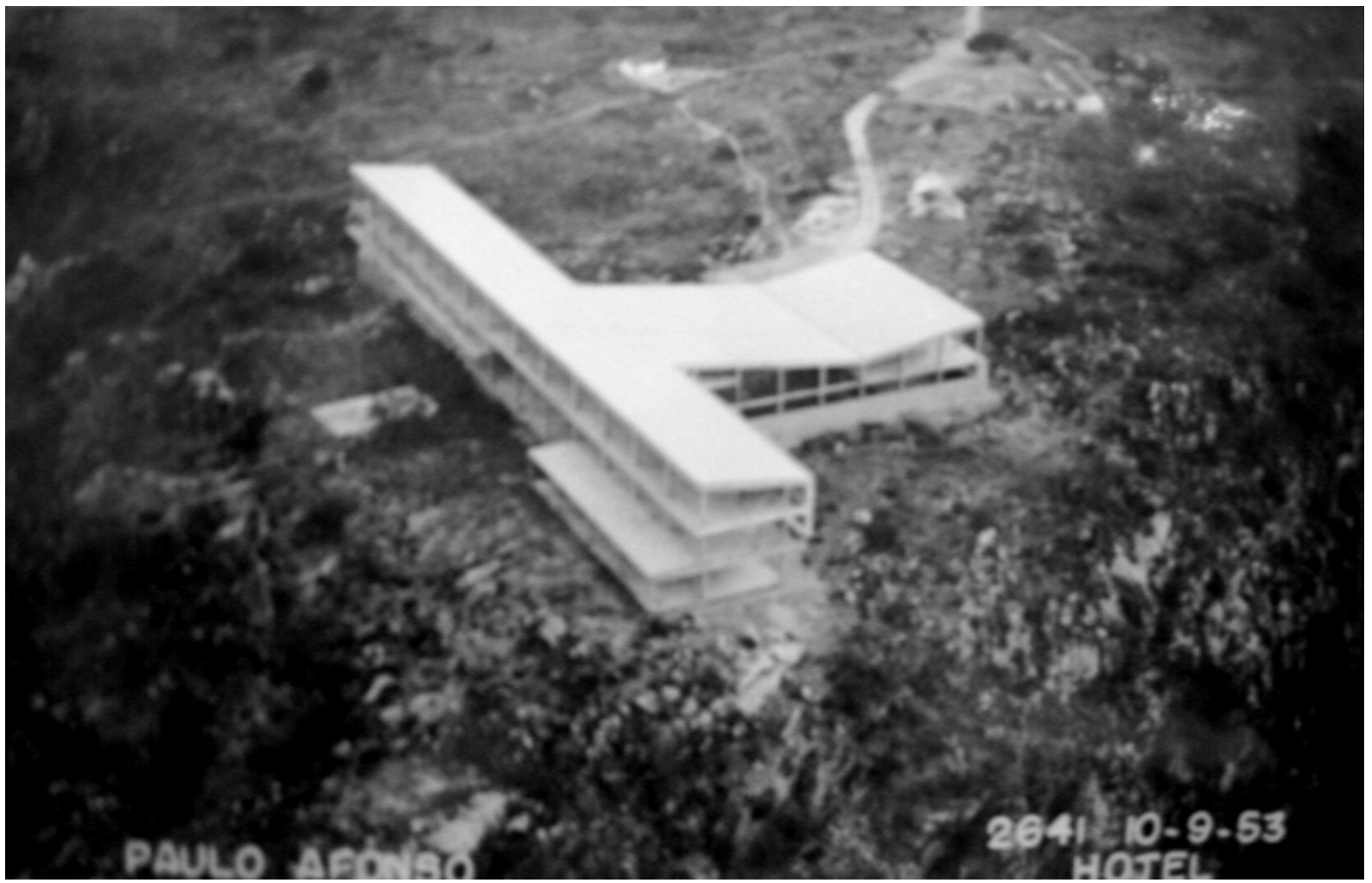

Figura 07: Vista aérea do Hotel Paulo Afonso, já com todo o esqueleto de concreto erguido, em 10 de setembro de 1953.

Fonte: Memorial da CHESF, Paulo Afonso.

Além disso, ao estruturar-se como um escritório de arquitetura e urbanismo e absorver a demanda gerada pelo Estado, em suas três esferas, pela elaboração de projetos arquitetônicos e urbanísticos para equipamentos de porte, o EPUCS viabilizou que a elaboração e o desenvolvimento da maior parte desses projetos passasse a ocorrer na própria capital baiana, o que até então não ocorria. Isso contribuirá diretamente na formação de toda uma geração de arquitetos e urbanistas locais que, tendo colaborado como desenhistas ou topógrafos desses trabalhos, receberam uma 
formação que a instituição formal de ensino local - a Escola de Belas Artes da Bahia (EBA-BA) - ainda não oferecia ${ }^{18}$.

Por fim, embora o próprio Diógenes Rebouças desenvolvesse pessoalmente a maior parte dos encargos projetuais citados, alguns projetos foram confiados pelo EPUCS - por indicação direta de Rebouças - a consagrados profissionais do Rio de Janeiro, como Alcides da Rocha Miranda, José de Souza Reis (autores do projeto do Centro Educativo de Arte Teatral - Teatro Castro Alves) e o paisagista Roberto Burle Marx (autor de projetos para as três praças centrais de Salvador: Terreiro de Jesus, Piedade e Campo Grande), ou tiveram sua autoria compartilhada com profissionais da Capital Federal, como Paulo Antunes Ribeiro (coautor com Rebouças do projeto do Hotel da Bahia $)^{19}$. Ao se encarregar de dar assistência a esses profissionais, municiando-Ihes com os dados solicitados e dando todo o apoio necessário ao bom desenvolvimento das suas atividades, a equipe técnica do EPUCS pôde realizar um rico intercâmbio de experiências e travar contato com alguns dos responsáveis diretos pelo reconhecimento internacional que a moderna arquitetura brasileira vinha obtendo.

Os Centros de Educação Elementar concebidos por Anísio Teixeira, Paulo de Assis Ribeiro e Diógenes Rebouças em 1948, formados por uma Escola-Parque e quatro Escolas-Classe - cuja única concretização se deu no Centro Educacional Carneiro Ribeiro (CECR) (FIGURA 08) -, estiveram baseados no plano do EPUCS e no esquema do centro cívico situado no centro do "trevo", que articula e serve às quatro "folhas"/bairros; no caso, o centro cívico ficaria na Praça Conselheiro João Alfredo (Largo do Tamarineiro), no Pau Miúdo, perto do qual foi localizada a Escola-Parque do CECR.

\footnotetext{
${ }^{18}$ A EBA-BA, criada em 1877 em Salvador como Academia de Belas Artes da Bahia, abrigava um curso de arquitetura desde o final do século XIX. Entretanto, poucos foram os arquitetos diplomados pela escola até meados do século XX: Fernando Fonseca (1984) registra que apenas 19 arquitetos se titularam entre 1920 e 1939 - uma média de um por ano -, e que, entre 1940 e 1950, não houve nenhum arquiteto diplomado. Esse quadro só foi modificado a partir da criação da Universidade da Bahia, com a incorporação da EBA-BA, em 1948; da sua federalização, em 1950; e, principalmente, da reestruturação do curso de arquitetura, promovida no início dos anos 1950.

19 Esse intercâmbio entre Diógenes Rebouças e os principais nomes da arquitetura moderna brasileira tinha se iniciado no início da década de 1940, quando, através de contatos facilitados por Mário Leal Ferreira, Rebouças procurou Lucio Costa, Oscar Niemeyer e outros colegas para que apreciassem o seu projeto para o Estádio da Fonte Nova (cf. ANDRADE JUNIOR, 2012a).
}

URBANA, V.5, nº6, mar.2013 - Dossiê: Urbanistas e Urbanismo- CIEC/UNICAMP 


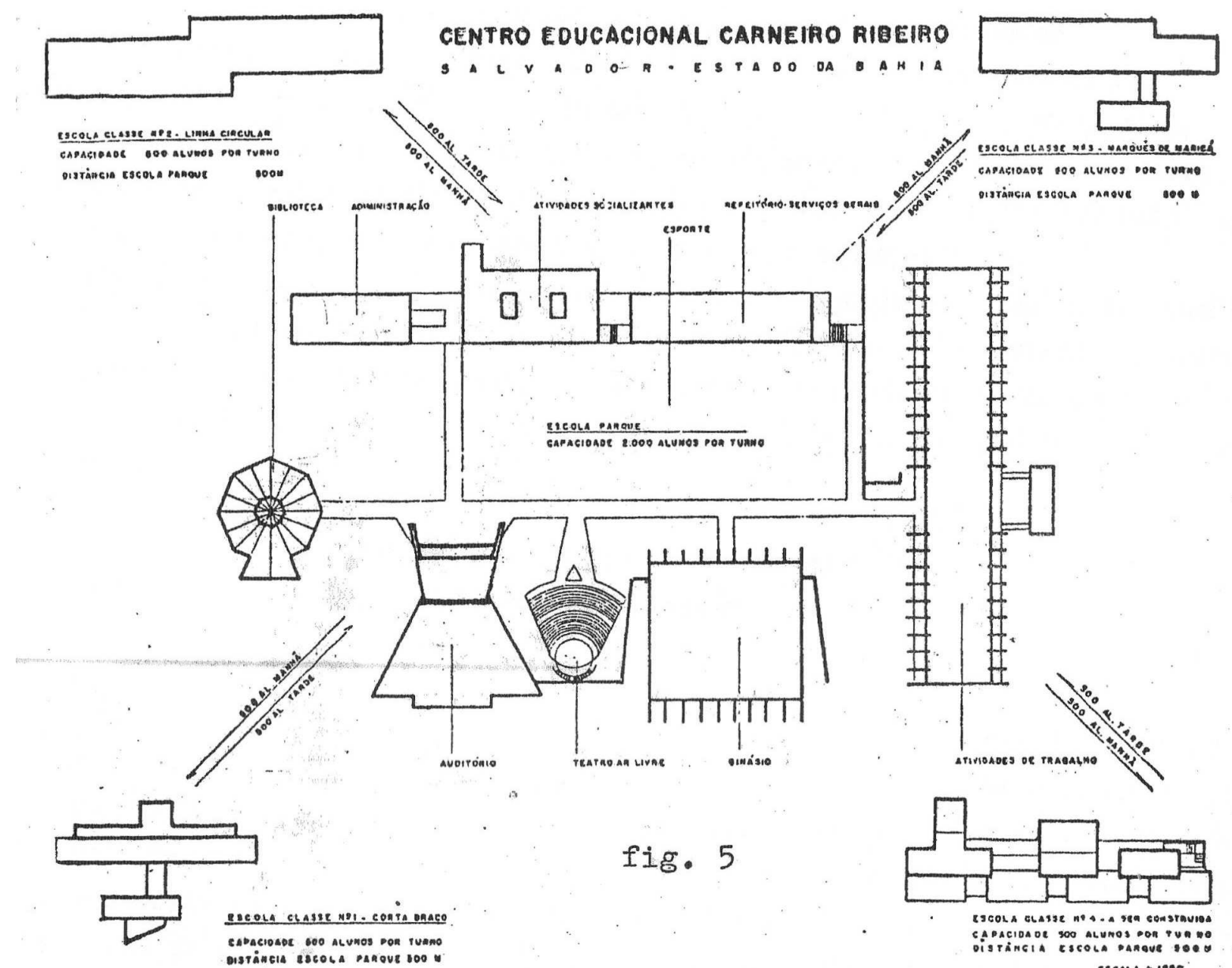

Figura 08: Esquema de funcionamento do Centro Educacional Carneiro Ribeiro - primeiro Centro de Educação Elementar construído em Salvador.

Fonte: DUARTE, 1973.

No que se refere aos projetos urbanísticos elaborados pelo EPUCS nesta segunda fase, destaca-se a Avenida do Centenário, desenhada pelo próprio Rebouças e cuja pedra fundamental foi lançada em 29 de março de 1949, no dia do 40 centenário de fundação da cidade (FIGURA 09). A Avenida do Centenário foi a primeira das vias de vale previstas pelo EPUCS a ser implantada em Salvador e foi aquela que mais se aproximou do conceito original: avenidas que "percorrem de preferência o fundo dos vales, dentro de parques ou bosques, subindo as encostas tão somente para atingir e cruzar as gargantas ou centros de abastecimento dos bairros residenciais, e logo mergulhar em ouro vale". Esta solução tinha como objetivo:

[...] proteger a Zona Residencial dos ruídos, poeiras, gazes de combustão dos veículos e acidentes que as vias lateralmente edificadas ocasionam, assegurando, a essas mesmas vias o tratamento especial que Ihes é imposto pelo tráfego expresso, isto é, rapidez, economia no desenvolvimento, resistência dos pisos ao desgaste por velocidades altas ou pesos excessivos, e precauções contra acidentes devidos a cruzamentos, curvas fechadas, etc. (SALVADOR, 1976, p. 98). 


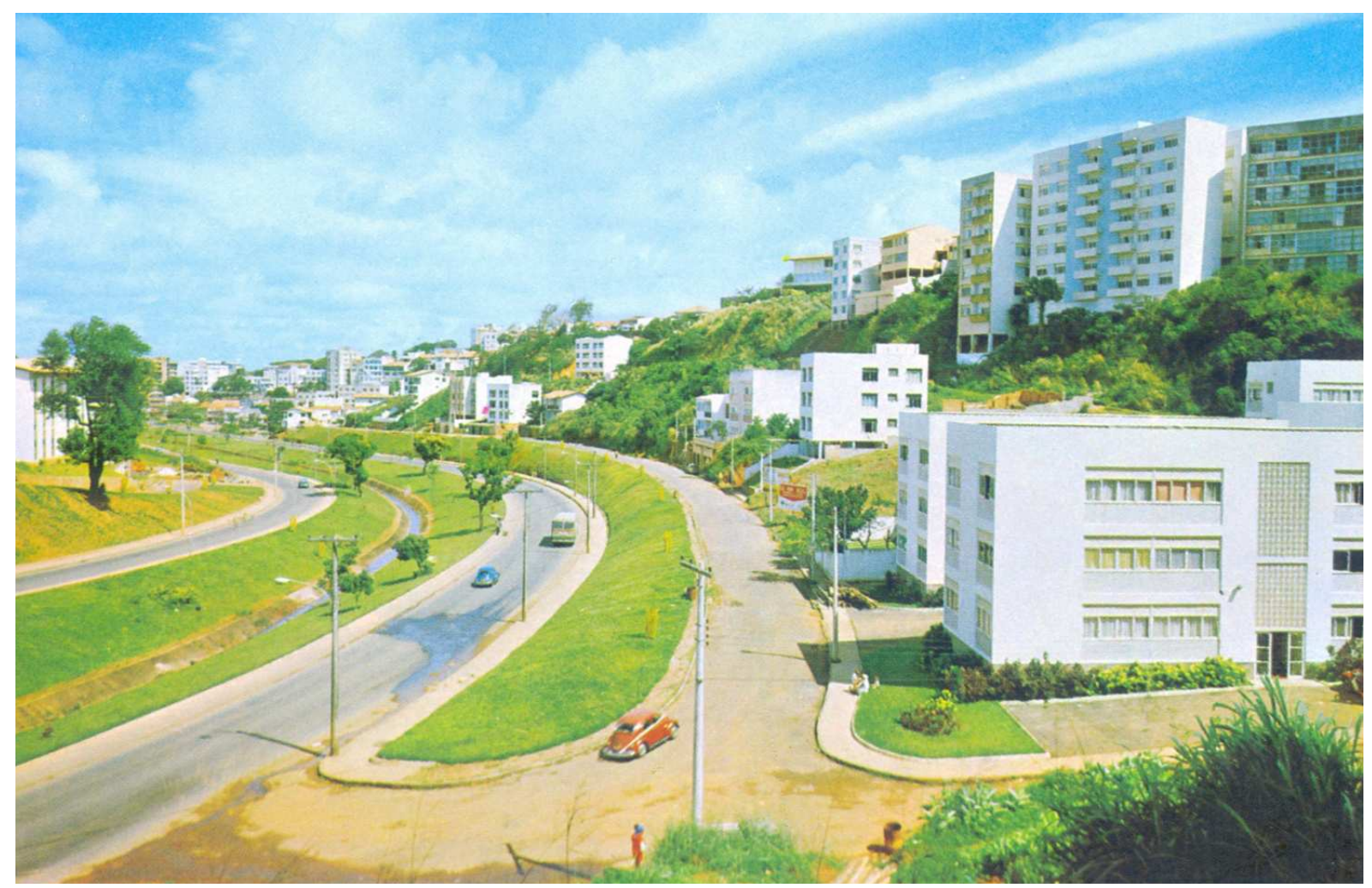

Figura 09: Avenida do Centenário, sem data: observar as duas vias expressas, nas laterais do talvegue do Rio dos Seixos, canalizado; e a via marginal, de acesso local, onde se encontra o automóvel vermelho; observar ainda a predominância de áreas verdes.

Fonte: Arquivo Histórico Municipal / Fundação Gregório de Mattos.

A Avenida do Centenário deveria ir "desde a Fonte Nova junto ao Grande Stadium em construção" - o Estádio da Fonte Nova - "beirando o Dique, aproveitando o quanto êsse pequeno lago tem de belo e pitoresco, à busca do vale do Garcia e do Vale do Campo Santo e Calabar, para chegar à Barra, à Avenida Oceânica e ao Jardim Brasil, pelo lindo vale do Chame-Chame" (SALVADOR, 1950, p. 47). O trecho do Chame-Chame, primeiro a ser concluído, foi inaugurado nos últimos dias da gestão Wanderley Pinho e do governo Mangabeira, em 30 de janeiro de 1951, junto com o Hotel da Bahia, o Terreiro de Jesus, os novos pavilhões do Parque Sanatorial Santa Terezinha e uma série de outras obras (NOVOS HOSPITAIS..., 1951, p. 02).

O Prefeito Wanderley Pinho defendeu, no relatório das ações executadas pela Municipalidade durante o ano de 1949 e apresentado à Câmara de Vereadores em 1950, que se tratava de "uma obra que, depois de pronta, ultrapassará a quasi todas, se não todas as que têm sido até agora feitas no perímetro urbano". Pinho a comparava a duas das obras de infraestruturação viária mais emblemáticas já realizadas em Salvador: a construção da Ladeira da Montanha (1878-1881), importante via de ligação entre as Cidades Alta e Baixa, e o alargamento da Avenida 
Sete de Setembro, promovido pelo Prefeito José Joaquim Seabra.(1912-1915) para ligar a Praça Castro Alves, no centro de Salvador, ao Campo Grande, ponto central dos novos bairros que permitiam a expansão urbana da cidade em direção ao sul. Pinho defendia, entretanto, que a Avenida do Centenário se destacava dessas intervenções por ser "não uma recomposição ou um melhoramento, mas uma criação, alguma cousa totalmente nova" (SALVADOR, 1950, p. 46-47).

O jornal $A$ Tarde publicou, um mês depois do lançamento da pedra fundamental, matéria com informações detalhadas sobre a nova avenida, então em construção e que "vai ser maior que a Avenida Paulista, em S. Paulo, e a Afonso Pena, em Belo Horizonte. Ficará com uma extensão de 4.800 metros, e uma largura variavel entre 28 a 52 metros, terminando no bairro da Barra" (LIGANDO BAIRROS..., 1949, p. 2). Evidentemente, uma obra desse porte não passaria incólume às críticas, como aquelas publicadas no editorial da última edição de 1949 de Técnica - Revista de Engenharia e Arquitetura: o Prefeito Wanderley Pinho é acusado de ter tomado um empréstimo no valor de Cr\$ 80.000.000,00 "a juros altos" para "gastar milhões anualmente sustentando o EPUCS nos seus devaneios cocainicos", dentre os quais a construção de "avenidas para 'por no chinelo' a Va Av. de N. York ou os Campos Elisios de Paris", como a "monumental [avenida] do Centenario" (UM PREFEITO..., 1949 , p. 4).

Dentre os projetos arquitetônicos elaborados por Diógenes Rebouças no EPUCS, também para a Prefeitura de Salvador, um dos mais singulares é, certamente, o do mercado de peixe nas proximidades do Forte de Santa Maria, no bairro da Barra, em Salvador (FIGURA 10). Construído entre 1949 e 1950, o novo mercado teve como objetivo abrigar a venda do pescado que já era realizada pelos pescadores da região em duas construções permanentes e grosseiras e em uma série de barracas improvisadas, montadas no horário da venda do peixe.

A intervenção, projetada por Rebouças, incluía o "embelezamento" da diminuta praça fronteiriça à fortificação e ao mercado e delimitada pela praia do Porto da Barra e pela Avenida Sete de Setembro. A intervenção na praça consistiu na pavimentação em conchas, seixos rolados e calçamento em mosaico português, com pedras pretas e brancas, além da instalação de bancos e frades de amarração em pedra lioz, da construção de cais ao longo da praça e de uma rampa de acesso aos saveiros (SALVADOR, 1950, p. 44; SALVADOR, 1951, p. 19). 


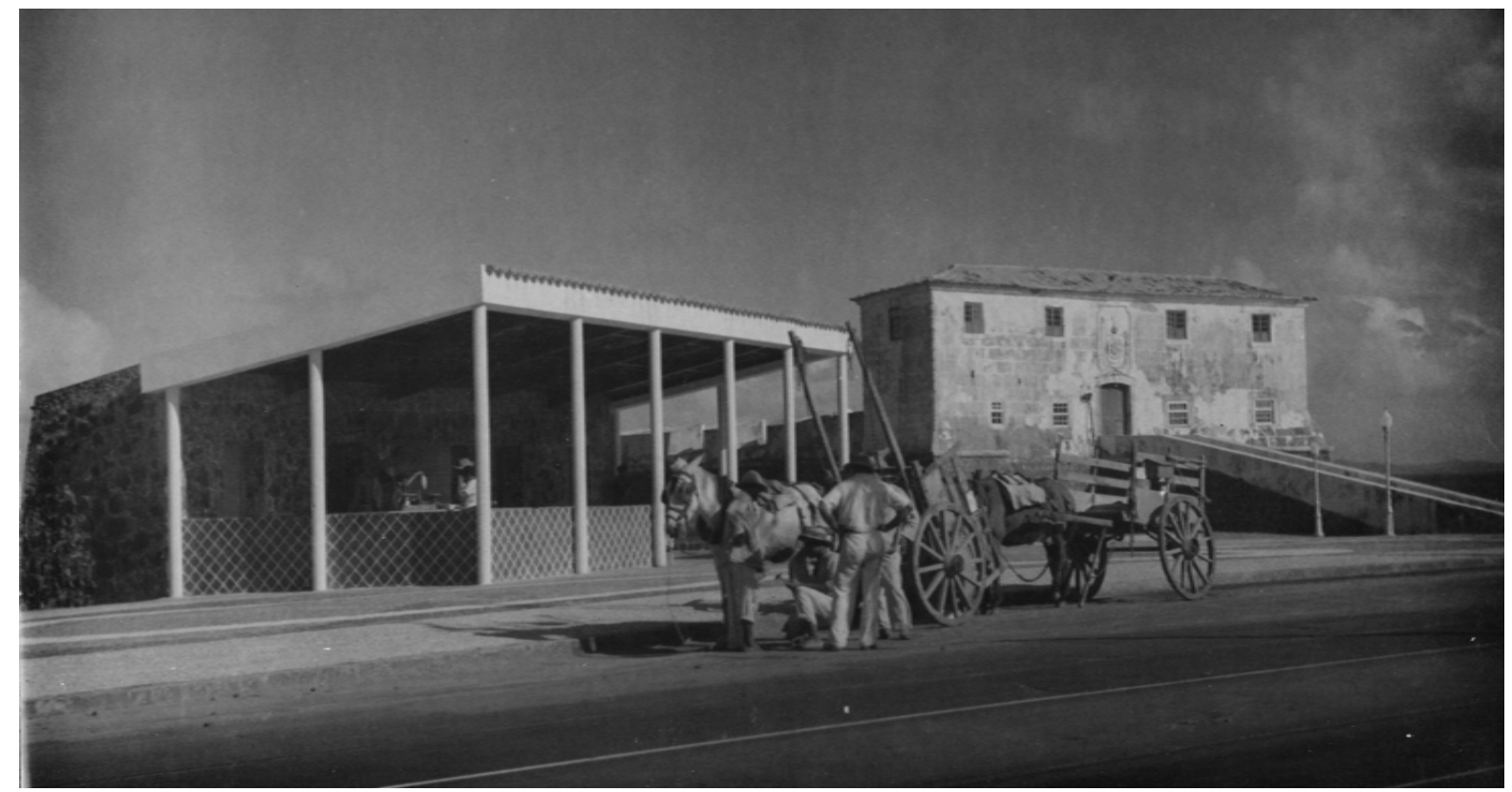

Figura 10: Vista do mercado de peixe, projeto de Diógenes Rebouças, junto ao Forte de Santa Maria.

Fonte: CEAB/FAUFBA.

O projeto do novo mercado demonstra sua preocupação com a preservação da ambiência do pequeno forte do final do século XVII que as construções anteriormente existentes não tinham; ademais, denuncia a capacidade incomum de Rebouças de realizar uma arquitetura que concilia, ao mesmo tempo, uma extrema delicadeza e uma profunda simplicidade. O novo mercado corresponde à justaposição de dois elementos bastante distintos, resultando em uma arquitetura heterogênea, porém coerente. A primeira é a maior e corresponde a uma levíssima varanda, com cobertura em telhas cerâmicas e estrutura de madeira que se apoia sobre vigas periféricas pintadas de branco; estas vigas, por sua vez, apoiam-se em um conjunto de dez esbeltos pilotis, também pintados de branco. Entre os pilotis, uma mureta baixa, revestida com peças cerâmicas, delimita com clareza os espaços interno e externo. A segunda corresponde a um minúsculo volume maciço em alvenaria de pedra aparente, que abriga os espaços de apoio aos pescadores e cujas únicas aberturas são as portas que o ligam à varanda.

No que se refere aos projetos realizados para o Governo do Estado pelo EPUCS e desenhados por Rebouças, um dos mais importantes foi a nova Penitenciária do Estado (1949-1950), sobre a qual Paulo Ormindo de Azevedo observou que, "embora com roupagem moderna, foi concebida dentro da tradição dos cárceres panópticos 
oitocentistas, com um pátio circular e torre central de vigilância" (AZEVEDO, 1997, p. $191)^{20}$ (FIGURA 11).

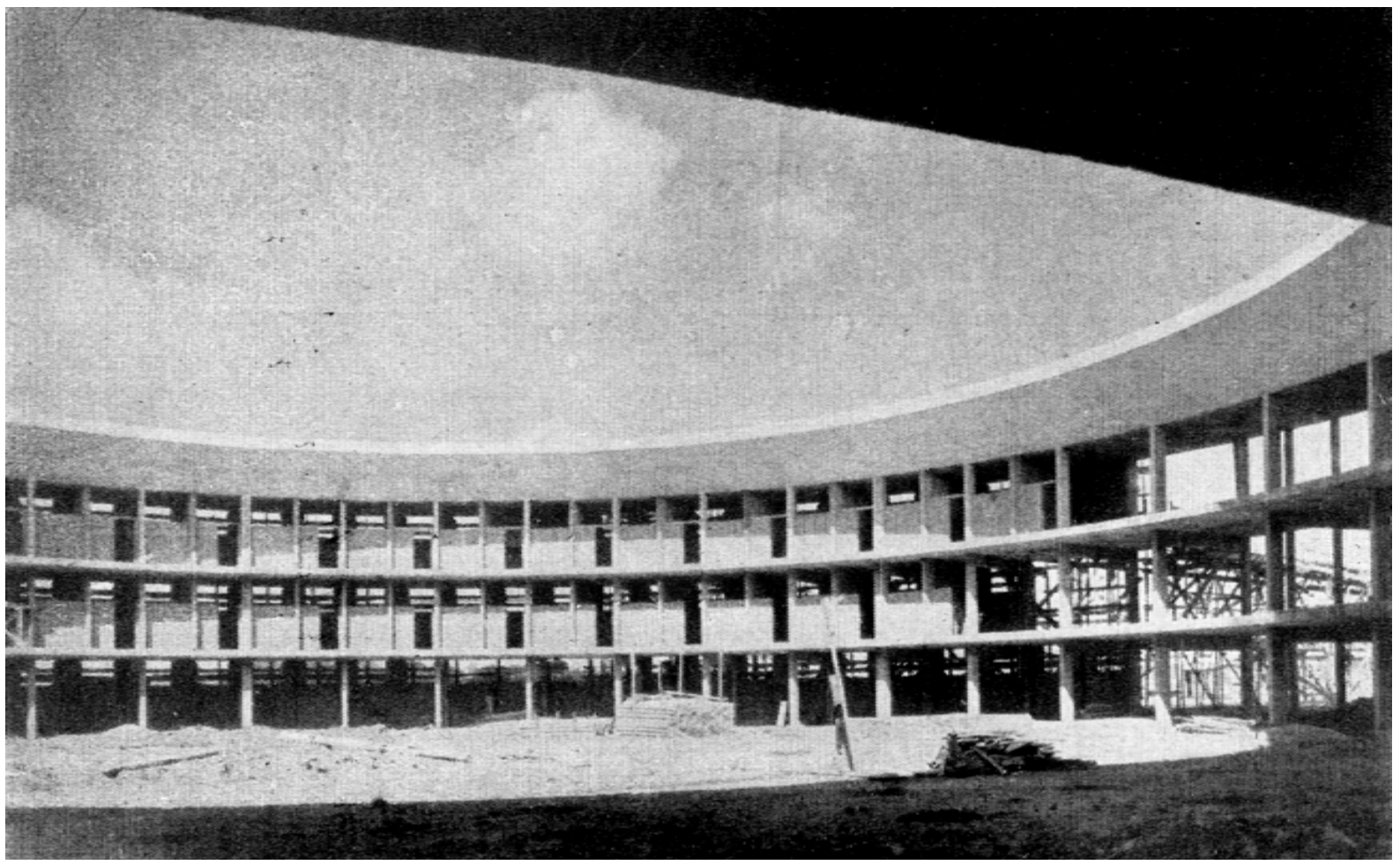

Figura 11: Penitenciária do Estado: pátio interno do pavilhão celular maior, ainda em construção, no início dos anos 1950.

Fonte: SALVADOR, 1954.

O EPUCS, contudo, não se limitava a elaborar projetos para edifícios e espaços públicos: entre 1949 e 1950, desenvolveu diversos estudos para loteamentos privados. Frente à ausência de legislação urbanística em vigor que consolidasse, de forma objetiva, os parâmetros estabelecidos pelo EPUCS, bem como face à necessidade de desapropriação de áreas nos terrenos em questão para a implantação de infraestrutura urbana a cargo da Prefeitura, os engenheiros da Divisão de Urbanismo da Prefeitura a serviço do EPUCS, como Antônio Rebouças - o irmão caçula de Diógenes ${ }^{21}$ - e João Augusto Calmon, ao receber as demandas de informações e parâmetros por partes das empresas responsáveis pela implantação desses

20 Em Vigiar e Punir, Michel Foucault identificou o panóptico, concebido pelo filósofo e jurista inglês Jeremy Bentham no final do século XVIII, como "o princípio geral de uma nova 'anatomia política' cujo objeto e finalidade não são as relações de soberania, mas as relações de disciplina" (FOUCAULT, 1987, p. 173, grifo nosso). Segundo Foucault, o poder disciplinar, desde o início do século XIX, se serviu "dos procedimentos de individualização para marcar as exclusões"; o panóptico, um dispositivo aplicado não só à arquitetura prisional mas também a manicômios, sanatórios e até mesmo escolas, seria o maior símbolo desse poder disciplinar, pois "automatiza e desindividualiza o poder", dado que "tem seu princípio não tanto numa pessoa quanto numa certa distribuição concentrada dos corpos, das superfícies, das luzes, dos olhares" (FOUCAULT, 1987, p. 167).

${ }^{21}$ Antônio de Almeida Rebouças nasceu em Itabuna, em 1922, e graduou-se em engenharia civil pela Escola Politécnica da Universidade da Bahia em 1948. 
loteamentos, terminavam por apresentar propostas urbanísticas aos requerentes, desenhadas em escala, a partir da base cartográfica elaborada pelo EPUCS.

Por exemplo, em 12 de fevereiro de 1949, a Companhia Comércio, Imóveis e Construções S.A. enviou ofício à Prefeitura, informando que, no intuito de "estudar o aproveitamento dos seus terrenos" localizados no Chame-Chame e na Fazenda Camarão, no bairro da Barra, "atingidos pelo plano da Avenida do Centenário", requeria "as normas e os plano [sic] a que deve obedecer o loteamento dessa zona", bem como uma cópia heliográfica do levantamento aereo fotogrametrico do trêcho em questão, afim de melhor demarcar os limites da sua propriedade". Três meses depois, foi encaminhado à requerente um "estudo para loteamento" assinado pelo engenheiro Antônio Rebouças em escala 1:1000, com traçado do sistema viário, parcelamento com definição de todos os lotes e uma série de outras informações. No ofício em que encaminhava o estudo ao engenheiro-chefe da Divisão de Urbanismo da Prefeitura, datado de 09 de maio de 1949, Antônio Rebouças informava que havia "procedido aos devidos estudos sobre o plano de loteamento para o terreno" em questão, e que anexava "uma copia da sugestão estudada, mostrando os limites do referido terreno assim como a situação do mesmo em relação às avenidas Presidente Vargas e ramal da Avenida Centenário"22.

Do seu papel inicial de instância definidora de parâmetros de atuação, o EPUCS se transformara em definidora direta de traçados, de parcelamentos ${ }^{23}$ e dos projetos que promoveriam a efetiva transformação física da cidade - e, para tanto, contou com a participação de respeitados profissionais do Rio de Janeiro. Sob a coordenação de Diógenes Rebouças, portanto, o EPUCS se tornou, entre 1947 e 1950, em um escritório estatal de arquitetura e urbanismo, elaborando dezenas de projetos para a Prefeitura e, principalmente, para o Governo do Estado. Constituiu-se, também, no principal centro de formação dos jovens profissionais, face às deficiências do único curso de arquitetura então existente no Estado; teve, ainda, papel fundamental na consolidação da arquitetura e do urbanismo modernos e na autonomização do respectivo campo na Bahia. Apesar disso, a historiografia sobre o

\footnotetext{
${ }^{22}$ Arquivo Histórico Municipal / Fundação Gregório de Mattos, Acervo cartográfico, distrito da Vitória, ano 1949, tema: Loteamento de terreno, local: Chame-Chame e Fazenda Camarão, proprietário(a): Cia. Comércio Imóveis e Construções S.A.

${ }^{23}$ Além do loteamento Chame-Chame / Fazenda Camarão, no levantamento que realizamos junto ao Arquivo Histórico Municipal / Fundação Gregório de Mattos da Prefeitura Municipal de Salvador, pudemos identificar outras três propostas de loteamentos que os engenheiros Antônio Rebouças e João Augusto Calmon elaboraram, na condição de servidores municipais, para empresas e clientes privados entre 1949 e 1950: Ioteamento na Avenida Princesa Isabel, na Barra, também para a Companhia Comércio, Imóveis e Construções S.A.; loteamento Rio de São Pedro, na Graça, em terrenos do espólio de João Manuel Alban Garrido; e loteamento na Barra, em terrenos de João Aurino de Souza Teixeira.
} 
urbanismo moderno na Bahia raramente aborda essa segunda fase do EPUCS, sob a coordenação de Rebouças, limitando-se a analisar a primeira fase, sob a coordenação de Mário Leal Ferreira. É o papel de Rebouças na consolidação da arquitetura e do urbanismo modernos na Bahia que pretendemos resgatar com esse artigo.

\section{Referências}

A BAHIA TERÁ uma Penitenciaria-Modelo (1950). A Tarde, Salvador, p. 02, 10 fev 1950.

ANDRADE JUNIOR, Nivaldo Vieira de (2012a). O Complexo Esportivo da Fonte Nova em Salvador: A implosão de uma referência arquitetônica e paisagística. In: II ENCONTRO DA ASSOCIAÇÃO NACIONAL DE PESQUISA E PÓS-GRADUAÇÃO EM ARQUITETURA E URBANISMO, 2012, Natal. Anais.... Natal: Universidade Federal do Rio Grande do Norte, 2012 (CD-Rom).

ANDRADE JUNIOR, Nivaldo Vieira de (2012b). Arquitetura Moderna na Bahia, 1947-1951: Uma história a contrapelo. Tese (Doutorado em Arquitetura e Urbanismo) - Faculdade de Arquitetura - Universidade Federal da Bahia, Salvador, 2012.

ARAÚJO, Heloísa Oliveira de (1992). Inventário da Legislação Urbanística de Salvador: 1920-1966. As novas regras do jogo para o uso e o abuso do solo urbano. Dissertação (Mestrado em Arquitetura e Urbanismo) - Faculdade de Arquitetura Universidade Federal da Bahia, Salvador, 1992.

AZEVEDO, Paulo Ormindo de (1997) Diógenes Rebouças, um pioneiro modernista baiano. In: CARDOSO, Luiz Antônio Fernandes; OLIVEIRA, Olívia Fernandes de (org.). (Re) Discutindo o modernismo: universalidade e diversidade do movimento moderno em arquitetura e urbanismo no Brasil. Salvador: Mestrado em Arquitetura e Urbanismo da UFBA, 1997. p. 187-200.

BOURDIEU, Pierre (1977). Outline of a Theory of Practice. Cambridge: Cambridge University Press, 1977.

BRUAND, Yves (1981). Arquitetura Contemporânea no Brasil. São Paulo: Perspectiva, 1981.

CASAS POPULARES na Bahia (1952). A Tarde. Salvador, p. 02, 04 abr 1952. 
COMEÇOU o asfaltamento da Liberdade (1950). A Tarde. Salvador, p. 02, 06 fev 1950.

CONTINUIDADE na execução do plano de urbanismo (1949). A Tarde, Salvador, p. 02,28 maio 1949.

DUARTE, Hélio (1973). Escolas Classe, Escola Parque. São Paulo: FAUUSP, 1973.

FERNANDES, Ana (2008). Recuperação e disponibilização do acervo do EPUCS (Salvador-BA): Trabalho compartilhado e desafios. In: SEMINÁRIO LATINOAMERICANO ARQUITETURA E DOCUMENTAÇÃO, 2008, Belo Horizonte. Anais.... Belo Horizonte: Escola de Arquitetura - Universidade Federal de Minas Gerais, 2008 (CDRom).

FERNANDES, Ana; GOMES, Marco Aurélio A. de Filgueiras; SAMPAIO, Antonio Heliodório Lima (1999). Plano de Urbanismo do EPUCS - Escritório do Plano de Urbanismo da Cidade do Salvador, 1943-1947. In: LEME, Maria Cristina da Silva (coord.). Urbanismo no Brasil 1895-1965. São Paulo: Studio Nobel; FAUUSP; FUPAM, 1999. p. 412-415.

FONSECA, Fernando Luiz (1984). Apontamentos para a História da Faculdade de Arquitetura. Salvador: FAUFBA, 1984.

FOUCAULT, Michel (1987). Vigiar e Punir: nascimento da prisão. Petrópolis: Vozes, 1987.

GARZEDIN, Maria Aruane Santos (2004). A Negação da Figura e a Legalização do Vazio: urbanismo moderno, arte e espaço público em Salvador, Bahia - 1935-1974. Tese (Doctorado en Espacio Publico y Regeneración Urbana: Arte y Sociedad) Facultad de Bellas Artes - Universidad de Barcelona, 2004.

LIGANDO BAIRROS distantes (1949). A Tarde, Salvador, p. 02-08, 29 abr 1949.

MELLO, Eduardo Kneese de (1946). Impressões de uma viagem á Baia: Palestra realisada na Sociedade Brasileira de Cultura Inglesa. Acrópole, São Paulo, no 96, p. 317-320, abr 1946.

NOVOS HOSPITAIS para o combate à peste branca (1951). A Tarde, Salvador, p. 02, 29 jan 1951.

O CRESCIMENTO da cidade (1950). A Tarde, Salvador, p. 02, 16 ago 1950.

O E.P.U.C.S. também ameaçado de despejo (1949). A Tarde, Salvador, p. 02, 01 jun 1949. 
O HOTEL SERVIRÁ a toda a cidade (1950). A Tarde, Salvador, p. 02, 13 dez 1950.

O QUE FAZEM os Institutos (1951). A Tarde, Salvador, p. 02, 04, 14 fev 1951.

REBOUÇAS, Diógenes (1999). História do Fazer Moderno Baiano - entrevista de Diógenes Rebouças a Naia Alban e Anna Beatriz Galvão. Rua, Salvador, no 7, p. 116125, jul-dez 1999.

SALVADOR. Prefeitura Municipal da Cidade do Salvador (1949). Relatório apresentado à Câmara Municipal pelo Prefeito José Wanderley de Araújo Pinho por ocasião da abertura da sessão a 7 de abril de 1949. [Salvador,] Bahia: Imprensa Oficial, 1949.

SALVADOR. Prefeitura Municipal da Cidade do Salvador (1950). Relatório apresentado á Câmara Municipal pelo Prefeito José Wanderley de Araujo Pinho por ocasião da abertura da sessão a 7 de abril de 1950. [Salvador,] Bahia: Imprensa Oficial da Bahia, 1950.

SALVADOR. Prefeitura do Município do Salvador (1951). Obras Públicas na Administração Wanderley Pinho 1947-1951. [Salvador,] Bahia: Tipografia Beneditina, 1951.

SALVADOR. Órgão Central de Planejamento (1976). EPUCS: uma experiência de planejamento urbano. Salvador: Prefeitura Municipal de Salvador, 1976.

SAMPAIO, Antônio Heliodório Lima (1999). Formas Urbanas - Cidade Real \& Cidade Ideal. Contribuição ao estudo urbanístico de Salvador. Salvador: Quarteto: PPG/AUFAUFBA, 1999.

SANTOS NETO, Isaías de Carvalho (1993). Salvador: Cara \& Coroa. Salvador: Mestrado em Arquitetura e Urbanismo / Universidade Federal da Bahia, 1993. Pretextos, Série A, n. 03.

UM PREFEITO Pr'as Arabias (1949). Técnica - Revista de Engenharia e Arquitetura, Salvador, no 31, p. 4, nov-dez 1949.

VILA proletaria no Corta Braço. A Tarde, Salvador, p. 01, 29 dez 1947. 